\title{
O DIREITO ADMINISTRATIVO NO DIVÃ DO ESTADO CONSTITUCIONAL DE DIREITO: A TRAVESSIA DA LEGALIDADE PARA A JURIDICIDADE ADMINISTRATIVA
}

\author{
José Sérgio da Silva Cristóvam
}

Resumo: O presente ensaio aborda o tema da constitucionalização do Direito Administrativo, a partir dos contornos traçados pelo neoconstitucionalismo, enquanto paradigma teórico que propõe a superação do conjunto de teorias que marcam o positivismo jurídico, por meio da consolidação de um modelo fundado na prevalência da Constituição, na força normativa dos princípios constitucionais e na eficácia dos direitos fundamentais. A constitucionalização do Direito Administrativo induz à construção de um renovado regime jurídico administrativo, a partir dos princípios estruturantes da dignidade humana, do Estado democrático de direito e do princípio republicano, com a travessia da legalidade administrativa para a juridicidade administrativa, bases do novo paradigma da Administração Pública democrática.

1 Doutor em Direito Administrativo pela UFSC, com estágio de Doutoramento Sanduíche junto ao Instituto Superior de Ciências Sociais e Políticas (ISCSP) da Universidade Técnica de Lisboa (Portugal). Mestre em Direito Constitucional pela UFSC. Especialista em Direito Administrativo pelo CESUSC. Professor de Direito Administrativo nos Cursos de Graduação e Pós-Graduação em Direito do CESUSC. Professor de Direito Administrativo na Escola Superior da Magistratura do Estado de Santa Catarina (ESMESC) e na Escola Nacional de Administração (ENA/ Brasil), em convênio com a École Nationale d'Administration (l'ENA/França), bem como em Cursos de Pós-Graduação em Direito da UNIDAVI, UNOESC, UNISUL, UnC, Estácio de Sá e diversas outras instituições. Membro fundador do Instituto de Direito Administrativo de Santa Catarina (IDASC). Conselheiro Estadual da OAB/ SC (triênio 2013-2015). Vice-Diretor Geral da ESA-OAB/SC (triênio 2013-2015). Presidente do Comitê de Mobilização para a Reforma Política (OAB/SC). Membro da Comissão de Direito Constitucional e da Comissão da Moralidade Pública da OAB/SC (triênio 2013-2015). Assessor Jurídico do Sindicato dos Trabalhadores na Rede Estadual de Ensino de Santa Catarina (SINTE/SC). Advogado militante na seara do Direito Público. E-mail: jscristovam@gmail.com 
Palavras-chave: Estado constitucional de direito. Regime jurídico administrativo. Legalidade administrativa. Juridicidade administrativa. Administração Pública democrática.

\section{INTRODUÇÃO}

A atmosfera favorável à superação da tradicional dogmática jurídico-administrativa, com a construção de um renovado regime jurídico administrativo, vem sendo formada desde a eclosão do fenômeno de constitucionalização do Direito. No Brasil, pode-se dizer que a sua afirmação está diretamente relacionada ao advento da Constituição Federal e todo o seu alvissareiro processo sociopolítico de abertura democrática, a espraiar reflexos e ramificações nas mais diversas áreas da vida política, social, econômica e jurídica da nação.

A abertura constitucional trouxe à vida dogmática brasileira um denso e abrangente movimento de constitucionalização do regime jurídico administrativo, com a conjugação de parâmetros normativos que asseguram a edificação de um autêntico bloco normativo de Direito Administrativo constitucional, a representar a verdadeira espinha dorsal do sistema axiológico de limitações, parametrizações e regulamentações diretamente vinculativas da atividade administrativa.

É certo, por outro lado, que a construção do Direito Administrativo, enquanto disciplina autônoma e forjada sobre as bases de um regime jurídico especial, sempre esteve em muito relacionada ao conceito de interesse público e à teoria da supremacia do interesse público sobre o particular, elementos centrais de justificação e conformação estruturante do regime de prerrogativas e privilégios da Administração Pública, aqui designado como paradigma tradicional da supremacia do interesse público. ${ }^{2}$

2 Sobre o conceito de interesse público e os parâmetros do paradigma da supremacia do interesse público enquanto princípio estruturante do regime jurídico administrativo, inclusive com uma análise crítica dessa concepção, consultar: CRISTÓVAM, José Sérgio da Silva. O conceito de interesse público no Estado 
Entretanto, esse modelo de regime jurídico administrativo tem recebido qualificadas e cada vez mais recorrentes contestações. ${ }^{3} \mathrm{E}$ a superação dessa modelagem verticalizada do regime administrativo, fundado no princípio da supremacia do interesse público, traz consigo a necessidade de uma ampla reestruturação de vários institutos e conceitos ainda tradicionalmente reproduzidos, quase sem contestação, por boa parte da doutrina nacional e pelo conjunto de decisões dos tribunais, embora já dissonantes da matriz jurídico-administrativa contemporânea, tanto do ponto de vista lógico e axiológico como sob o prisma normativo-constitucional.

Tal superação justifica, inclusive, a revisão do modelo assimétrico e verticalizado de prerrogativas administrativas, algumas das quais amplamente desprovidas de respaldo constitucional, além do redimensionamento de uma série de princípios constitucionais administrativos, como a segurança jurídica, a proteção da confiança legítima dos cidadãos, a boa-fé, o controle social e democrático da Administração Pública etc. ${ }^{4}$

A partir das teorias cimeiras do constitucionalismo contemporâneo, amplamente difundido sob o rótulo de neoconstitucionalismo, em especial a defesa da supremacia da Constituição, a aplicação direta e imediata dos direitos e garantias fundamentais, a normatividade axiológica dos princípios constitucionais e a nova hermenêutica constitucional, ressurge um renovado regime jurídico administrativo, fundado na unidade da trinca principiológica estruturante da dignidade humana, do Estado

constitucional de direito: o novo regime jurídico administrativo e seus princípios constitucionais estruturantes. 2014. 379 f. Tese (Doutorado em Direito) - Programa de Pós-Graduação em Direito da Universidade Federal de Santa Catarina, Florianópolis, 2014, p. 100-166.

3 Para uma análise crítica do princípio da supremacia do interesse público, consultar: BINENBOJM, Gustavo. Uma teoria do Direito Administrativo: direitos fundamentais, democracia e constitucionalização. 2. ed. São Paulo: Renovar, 2008; SARMENTO, Daniel (Org.). Interesses públicos versus interesses privados: desconstruindo o princípio da supremacia do interesse público. Rio de Janeiro: Lúmen Júris, 2005.

4 Sobre essa temática, consultar: CRISTÓVAM, O conceito de interesse público..., p. 266-328. 
democrático de direito e do princípio republicano. Um modelo aberto, dinâmico, dialético e dialógico que pretende a superação daquela concepção impositiva, imperativa e autocrática da Administração Pública, com a construção de uma perspectiva compromissada com o respeito aos direitos e garantias dos cidadãos, a consensualidade e a participação social na formação das decisões administrativas, o que pode ser sintetizado na ideia de Administração Pública democrática.

Nesse debate insere-se a análise da superação da tradicional vinculação à legalidade administrativa pela vinculação à juridicidade administrativa, como modelo fundado na ideia de supremacia da ordem constitucional e no movimento de constitucionalização do Direito Administrativo.

\section{O ESTADO CONSTITUCIONAL DE DIREITO E A CONSTITUCIONALIZAÇÃO DO DIREITO ADMINISTRATIVO: UM DIÁLOGO NECESSÁRIO}

A concepção de Estado constitucional de direito revela um dos principais fenômenos jurídicos, políticos e filosóficos do Segundo Pós-Guerra. Erigido sobre os alicerces da teoria da supremacia da Constituição, da eficácia dos direitos fundamentais e da normatividade dos princípios jurídicos, representa elemento jurídico e ideológico de superação das ideias positivistas hegemônicas que reinaram soberanas nas fases anteriores do constitucionalismo moderno, sobretudo até a primeira metade do século XX.

\subsection{Estado constitucional de direito e neoconstitucionalismo}

$\mathrm{Na}$ intenção de oferecer uma proposta de reconstrução histórica, filosófica e teórica das bases desse novo constitucionalismo, Luís Roberto BARROSO propõe uma interessante abordagem do movimento de constitucionalização do Direito 
sobre aqueles três marcos fundamentais. Do ponto de vista histórico, destaca o constitucionalismo do Segundo Pós-Guerra na Europa, em especial na Alemanha e na Itália, com a redefinição do lugar da Constituição e a influência do Direito Constitucional sobre as instituições contemporâneas. No Brasil, ganha especial relevo o processo de redemocratização a partir de 1988, sob os auspícios e as promessas de uma nova ordem constitucional que, a exemplo do Moisés bíblico, ${ }^{5}$ reuniu as melhores esperanças do povo na "travessia do Estado brasileiro de um regime autoritário, intolerante e, por vezes, violento para um Estado democrático de direito", condição que "tem propiciado o mais longo período de estabilidade institucional da história republicana do país" (BARROSO, 2005, p. 234-235).

Do ponto de vista filosófico, o marco do Estado constitucional de direito e do neoconstitucionalismo convergem para o pós-positivismo, uma resultante dialética entre concepções do paradigma tradicional do jusnaturalismo moderno (filosofia natural do Direito) e elementos de um positivismo jurídico crítico (não dogmático), com a "superação - ou, talvez, sublimação - dos modelos puros por um conjunto difuso e abrangente de ideias, agrupadas sob o rótulo genérico de pós-positivismo" (BARROSO, 2005, p. 236-237).

Importa esclarecer que pós-positivismo e neoconstitucionalismo são aqui tomados como expressões sinônimas, ${ }^{6}$ a indicar

5 A alusão metafórica ao Moisés bíblico, aqui recuperada, na análise dessa travessia para o constitucionalismo de terceira dimensão, deve ser entendida em um duplo sentido. Serve para fazer referência ao longo processo de transição (travessia) que representa esse movimento ainda inacabado, assim como Moisés e o povo escolhido erraram pelo deserto por longos anos. Mas serve, também, para simbolizar a metáfora de tentações e provações que podem representar as sempre ardilosas e sedutoras armadilhas de fenômenos decisionistas, pouco ilustrados ou até despreocupados com a nova hermenêutica constitucional, quase sempre desinteressados ou pouco atentos ao ônus da justificação racional, base de correção (formal e material) e legitimação do modelo ponderativo de concretização da Constituição. O povo de Deus também passou por inúmeras provações na sua travessia até Terra Prometida, adorou falsos deuses e a eles erigiu templos e imolou oferendas. Nesse sentido, consultar: ÊXODO. In: A BÍBLIA SAGRADA. Tradução ecumênica. São Paulo: Paulinas, 2002.

6 Para uma análise do "neoconstitucionalismo" como equivalente ao "pós-positivismo", pode-se consultar o pensamento de Manuel Atienza. ATIENZA, Manuel. 
um conjunto de teorias multifárias e ainda em construção, com forte expressão e lastro na cultura jurídica a partir da segunda metade do século XX. Em comum, no mais das vezes, apresentam uma recorrente repulsa ao conjunto de teses puristas e formalistas centrais às tradicionais concepções de positivismo jurídico, sobretudo no que toca à relação (se contingencial ou genética) de tensão/integração entre Direito e moral.

A bem da verdade, não há como desvincular os debates doutrinários relacionados à passagem do positivismo jurídico para o neoconstitucionalismo, das profundas mudanças sociais e econômicas do final do século XIX e do século XX, desde a superação daquele modelo de Estado liberal-abstencionista (constitucionalismo de primeira dimensão) até a consolidação de um Estado social e democrático de direito (constitucionalismo de terceira dimensão). Tome-se para considerações o modelo kelseniano de positivismo jurídico estruturalista, entendido como uma teoria jurídica em que o direito positivo é único objeto da "ciência jurídica", denegatória de qualquer relação de necessária interação entre o Direito, a moral e a política.

Uma teoria jurídica assim estruturada até pode servir a um modelo de sociedade, aquele liberal-individualista, fundado nas insuficientes e desfocadas concepções de homogeneidade política e igualdade formal jurídica. Neste contexto, até seria cabível concordar (sob o prisma lógico-normativo) que um sistema de regras jurídicas estaria mais afinado à garantia da propriedade e as liberdades públicas em geral (segurança jurídica), inclusive o liberalismo econômico (mercado). Mas isso a que preço? Ao custo de um constrangedor e autofágico deficit de legitimação humanística derivado de uma imperdoável superação das preocupações com a promoção de direitos e interesses sociais.

Com efeito, desde o avanço para uma concepção prestacionista de Estado social (constitucionalismo de segunda

Entrevista a Robert Alexy. Cuadernos de Filosofía del Derecho, Alicante, n. 24, p. 671-687, 2001, p. 672-673. Em sentido semelhante, consultar: CADEMARTORI, Luiz Henrique Urquhart; DUARTE, Francisco Carlos. Hermenêutica e argumentação neoconstitucional. São Paulo: Atlas, 2009, p. 25-44. 
dimensão), palco efervescente dos movimentos de classe, da luta dinâmica de novos atores pelo pluralismo político, social e jurídico, já havia a construção de uma renovada atmosfera política e de um novo caldo de heterogeneidade social, forte o bastante para denunciar a necessária revisão das bases teóricas daquele discurso jurídico monolítico. Mas o ponto culminante desse processo somente eclodiria após os movimentos de autoritarismo e totalitarismo que varreram a Europa entre as terceira e quarta décadas do século XX (Nazismo, Fascismo, Stalinismo).

Neste quadrante, pode-se situar o discurso do pós-positivismo neoconstitucionalista como protagonista jurídico nessa tragédia pós-moderna de transformação sociopolítica e de emancipação humanística, contracenando com a crise de legitimidade e os problemas da indeterminação do Direito. E um dos seus principais elementos de cena são as teorias fundadas na concepção de estreita e necessária relação entre Direito, moral e política, na normatividade dos princípios constitucionais, na teoria substantiva dos direitos fundamentais e na hermenêutica constitucional, vetores centrais ao constitucionalismo de terceira dimensão. ${ }^{?}$

A compreensão da construção das bases filosóficas do neoconstitucionalismo impõe uma rápida digressão sobre algumas das concepções do constitucionalismo originário, aquele do Estado liberal ou "Estado de direito legislativo", como prefere Gustavo ZAGREBELSKI (1995). Neste modelo o legislador é o "senhor do direito", do que deriva uma total confusão entre lei e Direito, típica da Modernidade. O Direito é o que está na lei e a justiça é o que a lei determina. Assim, o conceito de justiça importa à ordem moral e não à ordem jurídica. A jurisdição é pautada pela previsibilidade e segurança

7 Para uma análise do pós-positivismo, inclusive sob variados enfoques político-jurídicos, consultar: CALSAMIGLIA, Albert. Postpositivismo. Cuadernos de Filosofía del Derecho, Alicante, n. 21-I, p. 209-220, 1998; BONAVIDES, Paulo. Curso de Direito Constitucional. 10. ed. São Paulo: Malheiros, 2000, p. 228-266; WOLKMER, Antonio Carlos. Pluralismo Jurídico: fundamentos de uma nova cultura no direito. 3. ed. São Paulo: Alfa Ômega, 2001. 
de um sistema fechado de regras jurídicas, guardiãs da propriedade privada e daquelas liberdades públicas caras ao "clube dos eleitos" (sociedade politicamente homogênea).

Mas este modelo de Estado legislativo, ainda que assecuratório de um considerável nível de segurança jurídica (sistema de regras), não poderia continuar a eternamente ignorar o insuprimível deficit de legitimidade do qual padecia, uma enfermidade crônica, fruto do seu insensível afastamento de quaisquer preocupações com os postulados de justiça material e igualdade substancial. A postura juspositivista de relegar à ordem moral as preocupações com os ideais de justiça e igualdade resultou em um enorme distanciamento do Direito de uma de suas funções primordiais: a consecução da justiça. Em uma paráfrase à sofisticada e poética metáfora política de George ORWELL (2007), todos eram iguais (perante a lei), mas uns poucos (bem poucos) eram muito mais "iguais" que os outros.

Retomando a proposta retrospectiva de BARROSO, o terceiro marco fundamental para a reconstrução da noção de Estado constitucional de direito reside na perspectiva teórica, quando são destacadas as três grandes transformações que "subverteram o conhecimento convencional relativamente à aplicação do direito constitucional: a) o reconhecimento de força normativa à Constituição; b) a expansão da jurisdição constitucional; c) o desenvolvimento de uma nova dogmática da interpretação constitucional" (BARROSO, 2005, p. 238-247).

Pode-se afirmar que, sob a roupagem da noção de Estado social e democrático de direito, o constitucionalismo de terceira dimensão repaginou suas estruturas teóricas fundamentais. $\mathrm{O}$ paradigma da força normativa da Constituição propõe o abandono daquelas vestes tradicionais da dogmática legalista (dogma da sujeição à lei) e sua transfiguração na sujeição à ordem constitucional, um sofisticado e hipnotizante figurino normativo aberto de regras e princípios, que pretende cortejar a tão sonhada justiça material. ${ }^{8}$

8 Para um estudo sobre a teoria dos princípios constitucionais, consultar: ÁVILA, Humberto. Teoria dos princípios: da definição à aplicação dos princípios jurídicos. 
Essa nova estética constitucional acaba por já não combinar com aquela figura do legislador como "senhor do direito", superada pelo importante (e ainda incógnito) agigantamento do papel constitucional dos juízes e tribunais, mas não como os novos "senhores do direito", situação incompatível e irreconduzível à própria perspectiva política e normativa do constitucionalismo contemporâneo, e sim no sentido (cada vez mais inflacionado) de protagonistas na defesa e concretização dos direitos fundamentais (de liberdade e prestacionais) (ZAGREBELSKI, 1995, p. 150-153).

Em suma, com as teorias do neoconstitucionalismo e a nova hermenêutica constitucional, vários princípios constitucionais são alçados à condição de normas estruturantes e fundamentais à ordenação constitucional. Abandona-se aquela dimensão fraca de princípios meramente programáticos e indicadores de linhas sugestivas às ações estatais e aos cidadãos, por uma teoria forte dos princípios constitucionais (pautas jurídico-axiológicas), anabolizados pela eficácia normativa e pela postura vinculativa ao Estado e aos particulares.

No Estado constitucional de direito os princípios constitucionais funcionam como verdadeiros veículos de justiciabilidade do Direito, os instrumentos de cultivo do sistema normativo pelas fecundas sementes do discurso prático (relações sociais, políticas e econômicas) e da justificação moral, reinserindo no palco central do debate jurídico aquelas esquecidas preocupações com a satisfação da justiça material. Pela via dos princípios jurídicos, as pautas valorativas, políticas, sociais e econômicas invadem a ordem normativa constitucional, reposicionando o vagão jurídico no trilho das preocupações que conduzem à justiça e à igualdade material. Isto representa um fator de consi-

4. ed. São Paulo: Malheiros, 2004; BONAVIDES, Curso de Direito Constitucional..., 2000; CRISTÓVAM, José Sérgio da Silva. Colisões entre princípios constitucionais: razoabilidade, proporcionalidade e argumentação jurídica. 1. ed. 4. tir. Curitiba: Juruá, 2011; ESPÍNDOLA, Ruy Samuel. Conceito de princípios constitucionais: elementos teóricos para uma formulação dogmática constitucionalmente adequada. 2. ed. São Paulo: Revista dos Tribunais, 2002. 
derável mitigação daquele insuprimível deficit de legitimidade do sistema, comum às doutrinas dos positivismos jurídicos de matizes dogmáticos e estruturalistas.

Nada obstante, contra as três concepções teóricas acima referidas, Dimitri DIMOULIS (2009) opõe interessantes objeções, até com a indicação da ausência de pertinência e mesmo de utilidade naqueles parâmetros de definição. Sobre a questão da força normativa da Constituição, sustenta que a "superioridade jurídica" e o "caráter material-valorativo-político" das Constituições sobre a legislação ordinária já é um fenômeno muito mais antigo, que remontaria ao início do século XIX (ou até antes disso). Prova disso seriam os exemplos de fiscalização e controle de leis inconstitucionais, o que desmistificaria a alentada relação do novo constitucionalismo com o período do Segundo Pós-Guerra.

$\mathrm{Na}$ questão da jurisdição constitucional e a tutela dos direitos fundamentais, embora não conteste a ampliação quantitativa do controle constitucional no Segundo Pós-Guerra, o autor sustenta que as bases da noção contemporânea de jurisdição constitucional já estariam lançadas desde o século XIX, com o sistema de controle de constitucionalidade estadunidense. Na mesma senda, adverte que a dimensão judicial (tribunais constitucionais) da tutela dos direitos fundamentais envolve muito mais uma questão de conjuntura política e institucional, havendo tribunais mais sensíveis e liberais na defesa dos direitos fundamentais, e outros mais "dóceis" ao poder político, sobretudo em Estados de feições autoritárias (DIMOULIS, 2009, p. 220).

Sobre a questão da nova hermenêutica constitucional, fundada na teoria dos princípios e no método de ponderação, ainda que também não desmereça a enorme difusão dessas teorias no constitucionalismo contemporâneo, o referido autor defende que essa opção metodológica não representaria qualquer traço de inovação, podendo ser encontrada nas suas mais diversas variantes teóricas já no discurso jurídico do século 
XIX ("equidade”, "espírito da lei”, "analogia”, "direito livre") (DIMOULIS, 2009, p. 221-222).

Não se pode desmerecer a qualidade das referidas objeções, sobretudo aquelas direcionadas ao fenômeno da jurisdição constitucional como traço de inovação do modelo de Estado constitucional de direito. Por outra quadra, parece inegável que o Segundo Pós-Guerra (para a Europa) e a atual Constituição Federal (para o Brasil) devem sim ser tomados como genuínas balizas históricas (políticas, ideológicas e humanísticas) para uma profunda e abrangente redefinição transformadora dos contornos da ordem constitucional, o que permite considerar esse caldo político, social e jurídico como um autêntico momento de ruptura para um novo paradigma constitucional, mais aberto, mais plural, mais humanista: o constitucionalismo de terceira dimensão. ${ }^{9}$

9 Sobre o papel de destaque e transformação que representou o advento da nova Constituição Federal para o discurso jurídico brasileiro, SAMENTO traz algumas interessantes considerações, a propósito das questões aqui debatidas. Nesse sentido: "O processo histórico que se desenrolou na Europa Ocidental a partir do final da Segunda Guerra, no Brasil só teve início após a promulgação da Constituição de 88. É verdade que já tínhamos controle de constitucionalidade desde a proclamação da República. Porém, na cultura jurídica brasileira de até então, as constituições não eram vistas como autênticas normas jurídicas, não passando muitas vezes de meras fachadas. Exemplos disso não faltam: a Constituição de 1824 falava em igualdade, e a principal instituição do país era a escravidão negra; a de 1891 instituíra o sufrágio universal, mas todas as eleições eram fraudadas; a de 1937 disciplinava o processo legislativo, mas enquanto ela vigorou o Congresso esteve fechado e o Presidente legislava por decretos; a de 1969 garantia os direitos à liberdade, à integridade física e à vida, mas as prisões ilegais, o desaparecimento forçado de pessoas e a tortura campeavam nos porões do regime militar. Nesta última quadra histórica, conviveu-se ainda com o constrangedor paradoxo da existência de duas ordens jurídicas paralelas: a das constituições e a dos atos institucionais, que não buscavam nas primeiras o seu fundamento de validade, mas num suposto poder revolucionário em que estariam investidas as Forças Armadas. Até 1988, a lei valia muito mais do que a Constituição no tráfico jurídico, e, no Direito Público, o decreto e a portaria ainda valiam mais do que a lei. O Poder Judiciário não desempenhava um papel político tão importante, e não tinha o mesmo nível de independência de que passou a gozar posteriormente. As constituições eram pródigas na consagração de direitos, mas estes dependiam quase exclusivamente da boa vontade dos governantes de plantão para saírem do papel - o que normalmente não ocorria. Em contextos de crise, as fórmulas constitucionais não eram seguidas, e os quartéis arbitravam boa parte dos conflitos políticos ou institucionais que eclodiam no país". SARMENTO, Daniel. O neoconstitucionalismo no Brasil: riscos e possibilidades. In: Filosofia e teoria constitucional contemporânea. Rio de Janeiro: Lumen Juris, 2009, p. 123-124. 
Não parece que seja necessário (nem possível) negar que aquelas referidas balizas históricas, filosóficas e teóricas já estariam mesmo presentes no período anterior ao Segundo Pós-Guerra. Algumas já coabitam (em forma) o universo do primeiro constitucionalismo (Estado liberal) e das constituições de finais do século XVIII (Constituições estadunidense em 1787 e francesa de 1791), mantendo-se, inclusive, no segundo constitucionalismo (Estado social). Mas isso não autoriza ou justifica desconsiderar ou diminuir o fato inquestionável de que os seus contornos conceituais, normativos e filosóficos somente foram eclodir, em potência e espírito de reformulação, com o advento do modelo de Estado constitucional de direito, na perspectiva substantiva do Estado social e democrático que passou a se consolidar na Europa do Segundo Pós-Guerra e, no Brasil tardio, somente com o advento da chamada Constituição Cidadã.

Sobre essas questões, Lenio Luiz STRECK chega a falar em uma autêntica "revolução copernicana provocada pelo neoconstitucionalismo", sobretudo a partir da nova hermenêutica constitucional, uma ruptura paradigmática fundada no caráter transformador do Estado social e democrático, o que em países como o Brasil assume relevância ímpar, com a Constituição passando a gestar "no seu interior as possibilidades de resgate das promessas incumpridas da modernidade" (STRECK, 2005, p. 521-523).

Em suma, para uma visão panorâmica desse fenômeno de ruptura que representa o movimento de "constitucionalização do ordenamento jurídico”, ressoa conveniente recuperar a esclarecedora síntese do jurista italiano Ricardo GUASTINI, quando apresenta um quadro de condições a serem observadas em um ordenamento jurídico, para que receba o carimbo de "impregnado" pelos ventos do novo constitucionalismo: 1 . Constituição rígida (escrita e com mecanismos de proteção das normas constitucionais), que albergue direitos fundamentais; 2 . Garantia jurisdicional da supremacia da constituição (sistema 
de controle de constitucionalidade das normas jurídicas); 3 . Força vinculante da Constituição, sob um conjunto de normas prescritivas e não somente programáticas (manifesto político); 4. Modelo de Constituição invasiva (sobreinterpretación), pela via da interpretação extensiva e que permita deduzir da ordem constitucional o seu conjunto de princípios implícitos; 5. Aplicação direta e imediata das normas constitucionais, limitadoras do poder político estatal e também regentes das relações sociais privadas; 6. Modelo de interpretação conforme a Constituição, com o fortalecimento da ordem constitucional; 7. Influência da Constituição no debate político, que deve ser substancialmente observada na relação entre os órgãos constitucionais e todos os atores políticos, inclusive os juízes e tribunais. ${ }^{10}$

Vale ressaltar que, no modelo constitucional brasileiro, todas essas condições de constitucionalização são presenças radicais e substanciosas, como servem de exemplo o sólido sistema de blindagem constitucional; a garantia da supremacia da Constituição (mecanismos diferenciados para a reforma constitucional e cláusulas pétreas); uma prodigiosa e abrangente carta de direitos fundamentais (individuais e coletivos); um amplo sistema de controle de constitucionalidade (ação direta de inconstitucionalidade, ação declaratória de constitucionalidade, arguição de descumprimento de preceito fundamental, ação direta de inconstitucionalidade por omissão, mandado de injunção); afora os modelos de interpretação sistemática e interpretação conforme a Constituição (declaração de inconstitucionalidade com redução de texto, declaração de inconstitucionalidade sem redução de texto, interpretação conforme a Constituição).

10 Sobre a análise dessas condições de constitucionalização, GUASTINI defende que os itens 1 e 2 representam efetivas condições necessárias de constitucionalização, no sentido de que a sua ausência sequer permite conceber a ideia de constitucionalização. Por outro lado, os demais itens (3 a 7) representam condições gradativo-qualitativas de constitucionalização, no sentido de um aprofundamento da metodologia constitucional. Inclusive, os itens 3, 4 e 5 estão visceralmente vinculados, o que permite dizer que, de certa forma, "no processo de constitucionalização 'tudo vai sendo cumprido'”. GUASTINI, Ricardo. La "constitucionalización" del ordenamiento jurídico. In: CARBONELL, Miguel (Org.). Neoconstitucionalismo(s). Madrid: Trotta, 2003, p. 50-58. 
Certamente, dentre todas as condições acima referidas, o maior deficit de constitucionalização no Brasil está na efetiva influência da Constituição no debate político. Ainda que o debate político-institucional tenha tomado a mídia e o cenário nacional, muitas vezes o discurso constitucional acaba sendo usado para acobertar "interesses de ocasião" e legitimar as mais egoísticas disputas entre grupos políticos. $\mathrm{O}$ fato de o debate constitucional estar na agenda diária da mídia, das instituições e da própria comunidade não significa (necessariamente) que se esteja levando a sério a Constituição. É necessário que o debate seja democraticamente qualificado e politicamente propositivo (inclusivo e não excludente; informativo e não deformativo). Mas isso depende de um processo educativo de convivência democrática e mesmo de cultura constitucional, com vias a consolidar um discurso político-institucional que se proponha a "levar a sério" a Constituição, sobretudo em seus aspectos materiais e no cumprimento das suas promessas emancipatórias.

\subsection{Direito administrativo e constitucionalização do direito}

Todos esses renovadores ventos de constitucionalização do Direito repercutem sensivelmente na seara jurídico-administrativa. ${ }^{11}$ Neste universo, o fenômeno da constitucionalização

11 Sobre o fenômeno da constitucionalização do Direito Administrativo, consultar: BARROSO, Luís Roberto. A constitucionalização do direito e suas repercussões no âmbito administrativo. In: ARAGÃO, Alexandre dos Santos; MARQUES NETO, Floriano de Azevedo (Coord.). Direito Administrativo e seus novos paradigmas. Belo Horizonte: Fórum, 2008, p. 31-63; DI PIETRO, Maria Sylvia Zanella. Da constitucionalização do Direito Administrativo: reflexos sobre o princípio da legalidade e a discricionariedade administrativa. In: DI PIETRO, Maria Sylvia Zanella; RIBEIRO, Carlos Vinícius Alves (Coord.). Supremacia do interesse público e outros temas relevantes do Direito Administrativo. São Paulo: Atlas, 2010, p. 175-196; FALDINI, Cristiana Corrêa Conde. A constitucionalização do Direito Administrativo. In: DI PIETRO, Maria Sylvia Zanella; RIBEIRO, Carlos Vinícius Alves (Coord.). Supremacia do interesse público e outros temas relevantes do Direito Administrativo. São Paulo: Atlas, 2010, p. 261-277; RODRÍGUEZ-ARANA MUÑOZ, Jaime. El marco constitucional del Derecho Administrativo: el Derecho Administrativo Constitucional. Anuario da Faculdade de Dereito da Universidade da Coruña, Coruña, n. 15, p. 87-102, 2011. 
tem operado uma verdadeira revolução transformadora, com a superação do paradigma tradicional da supremacia do interesse público e a construção do paradigma emergente, largamente influenciado pela centralidade do princípio da dignidade humana, pela teoria dos direitos fundamentais, pelo Estado democrático de direitos e pelo método de ponderação proporcional.

$\mathrm{Na}$ literatura jurídica nacional, cabe especial destaque à doutrina de Marçal JUSTEN FILHO, que chega a defender uma completa reestruturação da disciplina do Direito Administrativo, pela via da defesa e promoção dos direitos fundamentais. Nesta quadra, o administrativista pátrio já demonstra as tintas de sua proposição transformadora desde a definição do Direito Administrativo, que passa a ser concebido como o "conjunto de normas jurídicas de direito público que disciplinam as atividades administrativas necessárias à realização dos direitos fundamentais e a organização e o funcionamento das estruturas estatais e não estatais encarregadas de seu desempenho" (JUSTEN FILHO, 2005, p. 01).

Trata-se, efetivamente, de uma redefinição de sensível ruptura com aquela tradicional concepção estatalizada do Direito Administrativo, o que abre caminho para uma ampla revisão (ou até superação) de vários institutos e conceitos conformadores do regime jurídico administrativo. Um modelo radicalmente firmado na defesa e promoção dos direitos fundamentais, expressão jurídica densificadora por excelência do princípio da dignidade humana. ${ }^{12}$

Mas o renovado regime administrativo a ser estruturado não fica adstrito exclusivamente à centralidade da dignidade humana. Suas bases devem também dialogar e construir um espaço dialético de conjugação com as dimensões normativas decorrentes do Estado democrático de direito e do princípio republicano, trindade máxima de princípios estruturantes

12 Sobre os reflexos do reconhecimento e aplicação da dignidade humana como princípio estruturante do novo regime jurídico administrativo, consultar: CRISTÓVAM, O conceito de interesse público..., p. 268-283. 
fundamentais, a um só passo dinamites do edifício tradicional da teoria da supremacia do interesse público e esteios legítimos à construção do modelo de Administração Pública democrática, comum ao novo regime jurídico administrativo. ${ }^{13}$

No lugar da estática lógica da supremacia abstrata do interesse público sobre o privado, constitucionalmente insustentável sob vários aspectos (lógico, epistemológico, axiológico, ideológico e normativo-conceitual), desponta um renovado e dinâmico modelo de regime jurídico administrativo, sobre as bases do princípio da dignidade humana, do Estado democrático de direito e do princípio republicano, alçados à condição de verdadeiros princípios constitucionais estruturantes da unidade sistemática do edifício jurídico administrativo. ${ }^{14}$ Todo este turbilhão político-normativo inserido em um amplo, difuso, aberto e complexo contexto de constitucionalização do Direito, não irradia seu potencial de renovação apenas ao Direito Administrativo e seus institutos, mas à integralidade do discurso jurídico contemporâneo.

\section{A TRAVESSIA DA VINCULAÇÃO À LEGALIDADE ADMINISTRATIVA PARA A VINCULAÇÃO À JURIDICIDADE ADMINISTRATIVA}

A nova ordem constitucional faz transparecer ainda mais, e com destacada evidência, um fenômeno recorrente e universal, a crise da lei e da noção de legalidade como instru-

13 Sobre os reflexos do reconhecimento e aplicação do Estado democrático de direito e do princípio republicano como princípios estruturantes do novo regime jurídico administrativo, consultar: CRISTÓVAM, O conceito de interesse público..., p. 283-328.

14 A referência aos princípios da dignidade humana, ao Estado democrático de direito e ao princípio republicano, como a trindade de princípios estruturantes do novo regime jurídico administrativo, não quer significar que estes seriam os únicos princípios estruturantes da ordem constitucional como um todo, pois outras normas podem ter reconhecida essa dimensão conceitual-normativa e política, a exemplo dos próprios princípios federativo e da cidadania. A alusão à referida trindade principiológica, aqui entendido como unidade jurídico-sistemática, justifica-se pela sua direta e genética dimensão relacional com o regime jurídico administrativo, sobretudo a partir do fenômeno da constitucionalização do Direito (constitucionalismo de terceira dimensão). 
mentos reitores das comunidades políticas nos Estados democráticos contemporâneos. Esta crise da lei formal pode ser vista, primeiramente, sob um prisma filosófico-estruturalista, a revelar inclusive um denso desgaste do próprio modelo de democracia representativa, com um generalizado deficit de legitimidade dos órgãos parlamentares. Há, também, um aspecto normativo-funcional, relacionado ao desencanto e ao desprestígio da lei como fonte reguladora das condutas exigíveis das pessoas em geral e do Estado. Já não se crê na lei como uma profissão de fé, a sacrossanta síntese cristalina e racional expressão da vontade geral, nem como máxima fonte de regulação da vida pública ou privada (BINENBOJM, 2008, p. 125).

Para uma análise mais abrangente da referida crise da noção de lei, com destaque para a sua dimensão de legalidade administrativa, Gustavo BINENBOJM faz referência a cinco razões básicas, a começar pela questão fática decorrente da chamada inflação legislativa. A vertiginosa proliferação de leis, típica dos modelos jurídicos romano-germânicos, potencializada pelo mito positivista da completude do ordenamento jurídico e pelo agigantamento funcional do Estado social de direito, trouxe consigo uma espécie de banalização da lei, com uma considerável perda da sua centralidade e do seu poder simbólico. $\mathrm{Na}$ intenção de regular todos os aspectos das relações públicas e privadas, a inflação legislativa acabou por tornar impossível o conhecimento das leis, sacrificando uma das suas mais caras e importantes funções operativas, a promessa de certeza e segurança jurídica (BINENBOJM, 2008, p. 127-128).

Outra razão para a perda da centralidade da lei remete a uma triste e mesmo horrenda constatação histórica. Edificada como a expressão máxima da racionalidade, fator de limitação a todo e qualquer abuso de poder pelos homens, a história demonstrou que, para muito além de reproduzir quadros de profunda injustiça, a lei pode ser fundamento de legitimação para a própria barbárie humana, a exemplo dos modelos legalistas dos Estados nazi-fascistas que devastaram a Europa na 
primeira metade do "breve século XX" ${ }^{15}$ A lei não deu conta de refrear aquele signo de banalização do mal retratado por Hannah ARENDT (1989), na sua análise sobre os modelos totalitários de poder, produtores de algumas das mais profundas e vergonhosas cicatrizes da Humanidade. A dimensão formalista de validade das leis acabou por sepultar aquela "aura de superioridade moral que havia incorporado com a Revolução Francesa", o que permite falar em uma verdadeira "dessacralização da lei', pois a história provou que ela pode ser o veículo da injustiça e da falta de liberdade" (BINENBOJM, 2008, p. 128-129).

Há, ainda, outra forte razão de cunho filosófico, axiológico e normativo para a derrocada da lei na sua feição de proeminência como fonte do Direito, diretamente relacionada àquela indicada razão histórica, o que pode ser descrito como o fenômeno da constitucionalização do Direito. O constitucionalismo de terceira dimensão, típico dos modelos de Estado social e democrático de direito, acaba por representar o somatório axiológico-normativo das esperanças de justiça, liberdade e igualdade das comunidades políticas contemporâneas. A derrocada da lei formal, como fator máximo de limitação do poder e barreira à barbárie humana, faz nascer um novo culto e uma nova profissão de fé, a fé na Constituição.

O fenômeno da constitucionalização do Direito provoca, na seara do Direito Administrativo, um interessante e sofisticado movimento de substituição da legalidade, como fonte reitora da disciplina jurídico-administrativa, pela própria Constituição, fator de verticalização e direta parametrização normativa da atuação administrativa. Como identifica o administrativista lusitano Paulo OTERO, a "substituição da lei pela Constituição no fundamento do agir administrativo não ocorre apenas ao nível da definição das regras de competência dos órgãos da

15 A difundida expressão é do historiador e filósofo inglês Eric HOBSBAWM, quando traça uma qualificada análise das várias utopias totalitárias que varreram a Europa do século XX. Nesse sentido, consultar: HOBSBAWM, Eric. Era dos extremos: o breve século XX (1914-1991). Tradução de Marcos Santarrita. 2. ed. 26. tir. São Paulo: Companhia das Letras, 1995. 
Administração Pública, observando-se que também a própria atividade administrativa passa a encontrar no texto constitucional o critério directo e imediato de decisão" (OTERO, 2007, p. 740).

O fenômeno de verticalização e aplicação direta da Constituição pela Administração Pública, sem qualquer mediação legislativa (interpositio legislatoris), acaba por instituir uma autêntica substituição da normatividade da lei pela normatividade da Constituição, a representar a quebra daquele mito tradicional da onipotência da lei em face da Administração. A lei deixa de ser o único fundamento do agir administrativo. Nem o único nem o mais importante. Seu posto é tomado pela normatividade constitucional, o sistema de regras e princípios que incidem diretamente e funcionam como fator de justificação e legitimação do agir administrativo, o que OTERO define como "a ideia de uma osmose entre a Constituição e a lei que transforma aquela em norma habilitante do exercício da actividade administrativa" (OTERO, 2007, p. 733-735).

Sobre o tema, o constitucionalista português José Joaquim Gomes CANOTILHO também faz referência a situações em que a atividade administrativa funda-se diretamente na Constituição, no sentido de que "a precedência e a prevalência da Constituição substituem a precedência e a reserva vertical da lei”, ou seja, "a reserva vertical de constituição substitui a reserva vertical de lei”, sendo que a Constituição passa a fundamentar diretamente o agir administrativo, o que abre o caminho a uma espécie de "legalidade sem lei" (CANOTILHO, 2003, p. 840).

Em suma, a disposição da Constituição como perspectiva normativa direta e imediata da tomada de decisões pelo administrador público opera uma verdadeira revolução copernicana na dogmática jurídico-administrativa. Da estática e (no mais das vezes) fechada legalidade administrativa para a dinâmica, aberta e altamente complexa normatividade constitucional. Fica clara a diminuição daquela posição passiva do agente público, como mero executor das decisões político-legislativas, na medida em 
que assume uma vocação muito mais ativa, enquanto agente responsável pela densificação na normatividade constitucional, a partir de um processo de concretização ponderativa daqueles direitos e interesses assegurados pelo legislador constituinte.

A aplicação ponderativa da Constituição amplia sobremaneira a complexidade da atuação administrativa, sobretudo naqueles casos de decisões discricionárias, que passam a figurar integralmente submetidos à vinculação constitucional, ao conjunto de regras e princípios que compõem o bloco de normatividade constitucional.

Neste quadrante, OTERO chama a atenção para a questão do dever da Administração na defesa e promoção dos direitos fundamentais, independentemente da existência de mediação legislativa (interpositio legislatoris), a partir dos seguintes parâmetros: 1. A ausência de lei não exime ou impede os órgãos administrativos da implementação das atividades necessárias a sua consecução; 2. Mesmo existindo lei, as normas constitucionais servem como critério imediato de interpretação, integração e aplicação das normas pela Administração, sobretudo naqueles casos de exercícios de atividades discricionárias, concretização de conceitos indeterminados ou cláusulas gerais; 3. No caso de leis ostensivamente violadoras de direitos fundamentais, a Administração está vinculada à Constituição, pelo que as normas sobre direitos fundamentais são aplicadas "contra a lei e em vez da lei"; 4. A atividade administrativa violadora do conteúdo essencial de um direito fundamental é nula, ante a vinculatividade direta e imediata da Administração "às normas sobre direitos fundamentais” (OTERO, 2007, p. 740-741).

Como visto, a Administração Pública passa a uma direta vinculação ao cumprimento daqueles direitos e interesses definidos pelo legislador constituinte, sobretudo no caso dos direitos fundamentais (individuais e sociais), que a um só tempo funcionam como referencial normativo imediato para a atividade administrativa e também seu fator de validade constitucional e legitimação política. Na adequada síntese de BINEN- 
BOJM, "a atuação administrativa só será válida, legítima e justificável quando condizente, muito além da simples legalidade, com o sistema de princípios e regras delineado na Constituição, de maneira geral, e com os direitos fundamentais, em especial" (BINENBOJM, 2008, p. 132).

Outra razão da crise da lei formal refere-se à atual rivalidade e concorrência de outros atos normativos infraconstitucionais, capazes de servir de fundamento à atividade administrativa. Nesse sentido, pode-se apontar a sistemática das medidas provisórias (artigo 62 da CF/88), que no Brasil ganha ares de genuína inflação e invasão normativa do Executivo; a previsão de leis delegadas (artigo $68 \mathrm{da} \mathrm{CF} / 88$ ), na verdade um instituto pouco usado pelo Executivo; o cada vez mais ampliado e alargado campo da atividade normativa regulamentar da Administração, tanto pelo Chefe do Executivo (artigo 84, IV e VI da $\mathrm{CF} / 88$ ), como por autoridades administrativas independentes (poder normativo das Agências Reguladoras). ${ }^{16}$ Todas essas situações levam ao que BINENBOJM chama de paradigma da " "quase delegação' legislativa", uma espécie de "doutrina da deslegalização" que representa "um dos mais claros sinais de erosão da lei formal como condição da atuação administrativa". A rapidez com que os quadros econômicos e sociais se formam e reformam traz firme a exigência por celeridade nas respostas políticas do Estado, que devem vir acompanhadas por uma célere dinâmica normativa, sendo que este "clamor por velocidade e eficiência é bastante explícito no direito administrativo econômico, preocupado com uma eficiente atuação regulatória do Estado" (BINENBOJM, 2008, p. 132-133).

Uma última razão para a crise da lei formal diz respeito à fragilidade e à falta de independência dos órgãos parlamen-

16 Sobre o poder normativo das Agências Reguladoras, consultar: BRUNA, Sérgio Varella. Agências Reguladoras: poder normativo, consulta pública, revisão judicial. São Paulo: Revista dos Tribunais, 2003; CARVALHO FILHO, José dos Santos. Agências Reguladoras e poder normativo. Revista Eletrônica de Direito Administrativo Econômico (REDAE), Salvador, n. 9, p. 01-13, fev./abr. 2007. Disponível em: <http://www.direitodoestado.com/revista/REDAE-9-FEVEREIRO-2007-JOSE\%20CARVALHO.pdf>. Acesso em 03 fev. 2014. 
tares, que acabam por se deixar seduzir completamente pela ação política do Executivo, quer por meios legítimos de controle quer por aqueles métodos "menos ortodoxos" que povoam os noticiários jornalísticos da cena política. Neste quadrante, sobre os mecanismos normativos, não se pode desconsiderar a força político-institucional conferida ao Poder Executivo pela via do mecanismo constitucional de reserva de iniciativa legislativa para uma série de relevantes matérias (artigo 61, § 1० e artigo 63 da CF/88), o que define em larga medida a pauta do Legislativo. Há, ainda, os pedidos de urgência e trancamentos de pauta, inclusive no caso de não deliberação sobre medidas provisórias (artigo 64, \$§ $1^{\circ}$ e $2^{\circ}$ e artigo 62, § $6^{\circ}$ da CF/88) (BINENBOJM, 2008, p. 134-135).

O Poder Executivo acaba, na prática, por ditar o compasso e traçar os conteúdos da agenda parlamentar. Isso sem contar as estratégias políticas, mais do que recorrentes nas últimas décadas da vida pública brasileira, com a formação de sólidas bases parlamentares alinhadas ao governo, o que assegura a aprovação de praticamente todo e qualquer projeto governamental. Em última análise, o chamado fenômeno do "presidencialismo de coalizão", ${ }^{17}$ que dá vazão às mais criativas e absurdas alianças político-partidárias, nem sempre direcionadas à efetiva concretização de alvissareiros projetos para a nação, mas para atingir soluções momentâneas e aplacar sanhas mesquinhas e egoísticas, acaba por recuperar vivamente um traço daquela genética autoritária do legalismo administrativo.

Se as casas legislativas são amesquinhadas e reduzidas à condição de meros estágios de passagem (legitimação formal-procedimental) para projetos governamentais, a lei passa a ser

17 Sobre a problemática do chamado "presidencialismo de coalizão" no Brasil, consultar: ABRANCHES, Sérgio Henrique Hudson de. Presidencialismo de Coalizão: o dilema institucional brasileiro. Revista Dados - Revista de Ciências Sociais, Rio de Janeiro, v. 31, n. 1, p. 05-34, 1988; OLIVEIRA, Rafael Tomaz de. Presidencialismo de coalizão, um velho dilema brasileiro. Revista Eletrônica Consultor Jurídico, São Paulo, mai. 2013. Disponível em: <http://www.conjur.com.br/2013-mai-18/diario-classe-presidencialismo-coalizao-velho-dilema-brasileiro>. Acesso em: 02 fev. 2014. 
expressão quase que original da vontade do Executivo, o que faz sucumbir ao extremo e ofende o próprio núcleo essencial daquele tão propalado e tão pouco refletido princípio da separação de poderes. Nunca reverberou com tamanha presença aquela "genética autoritária" do Direito Administrativo, ${ }^{18}$ se operado a partir do princípio da legalidade administrativa. $\mathrm{Na}$ adequada síntese de OTERO, a "legalidade administrativa vinculativa da Administração Pública é, cada vez mais, o simples produto da vontade política do executivo que é imposta ao parlamento pela sua maioria partidária ou, em alternativa, é emanada pelo próprio executivo no exercício de poderes legislativos" (OTERO, 2007, p. 146).

Por todas essas razões, não há mais como conceber o agir administrativo a partir do entronamento solitário do princípio da legalidade como parâmetro de estrita vinculação positiva à lei. O Estado constitucional de direito reflete uma Administração Pública vinculada de forma aberta, complexa e dinâmica a todo o ordenamento jurídico, a partir da noção de parametrização vinculativa à juridicidade administrativa, à unidade normativa das regras e princípios extraídos da Constituição e das demais disposições normativas infraconstitucionais, desde que compatíveis com aquela. A ordem normativa constitucional passa a ser aplicável, inclusive, independentemente de mediação legislativa (interpositio legislatoris), sobretudo para aqueles casos de concretização dos direitos fundamentais, fonte máxima de legitimação e fundamento de validade constitucional do agir administrativo.

A dimensão da juridicidade administrativa, que tem seu conteúdo densificado a partir da aplicação (eficácia operativa) das normas constitucionais, acaba por englobar a própria legalidade administrativa, como um dos seus princípios conformadores, não mais como o princípio reitor da atividade administrativa, mas como um dos princípios a gravitar na constelação de normas vinculativas do universo jurídico-administrativo.

18 Sobre a referida "genética autoritária" do Direito Administrativo, consultar: CRISTÓVAM, O conceito de interesse público..., p. 79-89. 
Nesse sentido, BINENBOJM sustenta que: 1 . A atividade administrativa continua a operar, em regra, segundo a lei, se esta for constitucional (atividade secundum legem); 2. Mas a atividade administrativa pode retirar também fundamento diretamente da Constituição, independente ou para além da lei (atividade praeter legem); 3. E a atividade administrativa pode, eventualmente, legitimar-se ainda que contra a lei, a partir de uma ponderação desta "com outros princípios constitucionais (atividade contra legem, mas com fundamento numa otimizada aplicação da Constituição)" (BINENBOJM, 2008, p. 142).

Em síntese, a dimensão da juridicidade administrativa traduz-se na ideia de vinculação da Administração Pública a toda a ordem normativa constitucional e infraconstitucional, ao sistema de regras e princípios que fundam o ordenamento jurídico. A juridicidade administrativa pode tanto determinar a conjugação direta da normatividade constitucional ao agir administrativo, como pode justificar a atuação administrativa decorrente da vinculação estrita às leis e aos demais instrumentos normativos impositivos do agir da Administração Pública, desde que nos limites formais, procedimentais e substanciais da Constituição. ${ }^{19}$

De todas essas dimensões da atividade administrativa vinculadas ao parâmetro da juridicidade, certamente a mais polêmica e complexa é aquela que toca à atuação contra legem, a possibilidade de a Administração Pública negar aplicação a uma determinação legal impositiva de uma dada conduta estatal. Este ponto guarda, inclusive, relações diretas com o paradigma da ponderação de interesses.

Uma primeira questão relacionada à atuação contra legem refere-se à possibilidade de a Administração Pública negar aplicação a leis inconstitucionais, antes mesmo de qualquer

19 Para uma análise da pluralidade de fontes do Direito Administrativo contemporâneo, com destaque para as reflexões sobre o princípio da reserva de lei e sobre os atos normativos regulamentares na ordem jurídica brasileira, consultar: BINENBOJM, Uma teoria do Direito Administrativo..., p. 143-174. 
decisão pelo Poder Judiciário. ${ }^{20}$ Sobre o tema, BINENBOJM levanta algumas razões para sustentar a legitimidade desse tipo de decisão administrativa: 1 . A vinculação direta e imediata da Administração Pública à Constituição, com o dever de zelar pela sua supremacia; 2. A decisão administrativa de não aplicação da lei inconstitucional revela-se como condição de preservação da própria ideia de superioridade hierárquica da ordem constitucional; 3. Ainda que os Chefes do Executivo federal e estaduais estejam legitimados para propor ação direta de inconstitucionalidade perante o Supremo Tribunal Federal (artigo 103, I e V da $\mathrm{CF}$ /88), podem desde logo negar aplicação à lei havida por inconstitucional, porquanto a atribuição daquele tribunal não se traduz em monopólio da interpretação e aplicação da Constituição (BINENBOJM, 2008, p. 175-176).

A matéria é controvertida e exige reflexões. Imagine-se uma defesa de efeito direto e imediato no reconhecimento administrativo de inconstitucionalidade, mas somente para aqueles casos das chamadas leis manifestamente inconstitucionais? Isso traria outra questão problemática: o que se deve entender por leis manifestamente inconstitucionais?

Portanto, diante de uma legislação ao seu juízo inconstitucional, a Administração tem o dever de negar-lhe aplicação, sob pena de quebra da supremacia da Constituição e completa inversão da lógica hierárquica. Mas essa atuação administrativa deve estar cercada de alguns essenciais procedimentos de legitimação: 1. A não aplicação da lei havida por inconstitucional deve estar amparada em juízo decisório expresso da Administração Pública, pela autoridade administrativa competente (Chefe do Executivo), com base em parecer técnico-jurídico do respectivo órgão jurídico consultivo-normativo (motivação administrativa); 2. A decisão de não aplicação deve ter a devida

20 Sobre a questão da declaração de inconstitucionalidade de atos normativos pela Administração Pública e por tribunais administrativos, consultar: HARGER, Marcelo. A declaração de inconstitucionalidade de leis e ilegalidade de atos infranormativos por tribunais administrativos. In: NOHARA, Irene Patrícia; MORAES FILHO, Marco Antonio Praxedes de (Org.). Processo Administrativo: temas polêmicos da Lei nº 9.784/99. São Paulo: Atlas, 2011, p. 141-158. 
publicidade e ser aplicada em caráter geral (igualdade de tratamento); 3. O Chefe do Executivo tem o dever constitucional de submeter ao Poder Judiciário a referida controvérsia, pelas vias cabíveis, uma vez que a definitividade e a segurança jurídica sobre o tema somente decorrerão da manifestação judicial; 4 . A obrigação de submeter a matéria ao Poder Judiciário alcança, no caso do controle abstrato, inclusive os Chefes dos Executivos Municipais, se cabível a arguição por descumprimento de preceito fundamental (ADPF).

Mas a questão de atuação administrativa contra legem que produz maiores controvérsias diz respeito àquela possibilidade de decisões administrativas que afastem previsões legais específicas, para assegurar prevalência a outros princípios constitucionais, como os princípios da segurança jurídica, da boa-fé, da confiança legítima, da eficiência, da moralidade e da impessoalidade administrativa. Sobre o tema, BINENBOJM produz extensa análise para defender a possibilidade de ponderações administrativas contra legem, a partir da "configuração de uma equação de ponderação entre princípios constitucionais: de um lado, há, por reconhecimento expresso, a violação ao princípio da legalidade; de outro lado, a afronta ao princípio da segurança jurídica". Em casos tais, o autor sustenta que "eventual prevalência, em maior porção, da segurança sobre a legalidade não importa transigência com a ideia de Estado de direito, mas decorre de uma aplicação otimizada da Constituição" (BINENBOJM, 2008, p. 177-194).

O tema é também controvertido e reclama outras reflexões. Em primeiro lugar, importa considerar que o princípio da legalidade administrativa, embora destronado do Olimpo da disciplina jurídico-administrativa, ainda ostenta invulgar força normativa e justificativa à atividade administrativa, amparado que está (mais diretamente) em dois dos princípios estruturantes do regime jurídico administrativo, o Estado democrático de direito e o princípio republicano. Se constitucional, em regra, a lei deve ser o parâmetro do agir do Poder Público. 
Por outro lado, importa reconhecer que, em casos específicos, sobretudo naquelas situações de leis definidoras de procedimentos ao agir burocrático da Administração Pública ou leis restritivas de direitos fundamentais, a atividade de ponderação administrativa pode inclinar-se a negar prevalência à referida legislação, a fim de assegurar a otimizada aplicação da Constituição, a partir de outros princípios constitucionais dotados de maior densificação naquele caso concreto. Apenas para exemplificar, há inúmeras situações no cotidiano da prática administrativa em que a exigência legal de um emaranhado de procedimentos e burocracia irracionais acaba por inviabilizar a eficiência no gasto público e a adequada promoção da atividade administrativa. E não se está referindo a importantes exigências de garantia à publicidade, impessoalidade e moralidade administrativa, mas a meras ritualísticas míopes e chicanas injustificáveis (burocracias procedimentais), resquícios de um modelo atrasado de controle administrativo, ainda muito presente na forma de legislações atravancadoras do agir diária do Poder Público.

$\mathrm{Na}$ verdade, isso não significa uma defesa ampla e irrestrita da submissão da legalidade em favor da eficiência administrativa. Afinal, em um quadro ideal de Estado constitucional de direito, fundado em uma sólida democracia participativa, base de uma República genuinamente livre e igualitária, assecuratória do efetivo respeito à dignidade humana e aos direitos fundamentais, a Administração Pública eficiente é aquela que cumpre fielmente as leis. Mas estas devem ser a expressão substantiva das vontades e dos interesses resultantes do consenso firmado pela comunidade política (cidadania ativa e democracia participativa).

Por certo, uma análise realista impõe admitir-se que, em muitos casos, para cumprir fielmente a vontade constitucional e atingir a finalidade a que se destina, o Poder Público tem o dever de negar aplicação a determinadas leis, sobretudo quando restritivas de direitos fundamentais, o que pode encontrar 
respaldo no modelo de ponderação proporcional, com a aplicação direta e imediata do sistema de regras e princípios constitucionais (juridicidade administrativa). Uma perspectiva muito mais dinâmica, aberta, pluralista e complexa da atividade administrativa, a partir de um processo de legitimação fundado no cumprimento da Constituição e suas finalidades precípuas, a defesa e a promoção dos direitos fundamentais.

\section{CONCLUSÃO}

A construção de um renovado regime jurídico administrativo deve ser edificada sobre as bases do fenômeno do movimento de constitucionalização do Direito em geral, e do Direito Administrativo em especial. A constitucionalização do Direito, que no Brasil somente passa a operar mais firmemente a partir do advento da Constituição Cidadã, acaba por inaugurar um processo de reestruturação não somente das bases da teoria constitucional, mas da própria disciplina jurídica em geral, espraiando renovadas luzes e reflexos normativos em todas as direções e aos mais longínquos e recônditos espaços do universo jurídico nacional.

No âmbito da disciplina jurídico-administrativa, com a crise do modelo de subsunção normativa e da própria centralidade monolítica da legalidade administrativa, como fator único e insuprimível da atuação administrativa, emerge um novo padrão de justificação e funcionalidade do agir administrativo, a perspectiva da juridicidade administrativa, veículo normativo de travessia para uma perspectiva aberta, dinâmica e complexa de concretização do sistema constitucional de regras e princípios, a incidir e determinar o agir administrativo de forma direta e imediata, em muitos casos com a própria dispensabilidade da mediação legislativa.

A dimensão da juridicidade administrativa, fundada na densificação ponderativa da ordem constitucional, acaba por justificar mesmo a excepcional possibilidade de atuação admi- 
nistrativa contra legem, a partir da ponderação entre princípios constitucionais incidentes sobre o agir administrativo, capazes de racionalmente justificar o afastamento da legalidade administrativa, para assegurar a promoção de determinado direito fundamental ou o cumprimento de outros princípios e valores que, no caso concreto, demonstrem sólido lastro em condições fáticas e jurídicas de precedência.

A otimização das potencialidades aplicativas do novo regime jurídico administrativo exige a construção de uma matriz administrativa menos imperativa, impositiva, assimétrica e verticalizada. $O$ Estado constitucional de direito reclama um agir administrativo sob a perspectiva da consensualidade, da transparência, da construção de espaços abertos e democráticos de formação das decisões administrativas, do controle social e da eficiência da máquina pública. Em outras palavras: tem-se em vista um Estado que supere aquela tradicional ótica do horizonte social, político e jurídico sob arcaicas lentes que ainda veem súditos em vez de cidadãos, e que ainda aplicam muito mais um direito da Administração Pública do que aquele novo Direito Administrativo constitucionalizado, que brota cristalino dessa revigorada ordem constitucional e reclama aplicação direta, imediata e impositiva, inclusive em larga medida independente de mediações legislativas.

Todas estas questões permitem sustentar a existência das condições jurídicas instrumentais e substantivas de transição para um renovado regime jurídico administrativo, com a superação daquele paradigma tradicional estático, fundado na supremacia do interesse público e na lógica da assimetria e verticalização de prerrogativas e privilégios da Administração Pública. A ordem constitucional impõe a travessia para este Direito Administrativo renovado, mais democrático, republicano e inclusivo, capaz de pintar os corredores das repartições públicas e colorir as praças e esquinas da nação com toda aquela aquarela de propostas constitucionais libertárias e emancipatórias - paradigma da Administração Pública democrática. 


\begin{abstract}
This paper discusses the theme of constitutionalization of Administrative Law, from the contours traced by neoconstitutionalism, while theoretical paradigm that proposes to overcome the set of theories that characterize legal positivism, through the consolidation of a model based on the prevalence of the Constitution, in normative force of constitutional principles and effectiveness of fundamental rights. The constitutionalization of the Administrative Law induces to the construction of a renewed legal administrative system, from the structuring principles of human dignity, the rule of law and democratic republican principle, with the crossing of administrative legality for administrative jurisdicity, bases the new paradigm of Public Administration democratic.
\end{abstract}

Keywords: Constitutional rule of law. Legal administrative system. Administrative legality. Administrative jurisdicity. Public Administration democratic.

\title{
REFERÊNCIAS
}

ABRANCHES, Sérgio Henrique Hudson de. Presidencialismo de Coalizão: o dilema institucional brasileiro. Revista Dados - Revista de Ciências Sociais, Rio de Janeiro, v. 31, n. 1, p. 05-34, 1988.

ARENDT, Hannah. Origens do totalitarismo: anti-semitismo, imperialismo, totalitarismo. Tradução de Roberto Raposo Tavares. São Paulo: Companhia das Letras, 1989.

ÁVILA, Humberto. Teoria dos princípios: da definição à aplicação dos princípios jurídicos. 4. ed. São Paulo: Malheiros, 2004.

ATIENZA, Manuel. Entrevista a Robert Alexy. Cuadernos de Filosofía del Derecho, Alicante, n. 24, p. 671-687, 2001.

BARROSO, Luís Roberto. A constitucionalização do direito e suas repercussões no âmbito administrativo. In: ARAGÃO, Alexandre dos Santos; MARQUES NETO, Floriano de Azevedo (Coord.). Direito Administrativo e seus novos paradigmas. Belo Horizonte: Fórum, 2008, p. 31-63. 
. Neoconstitucionalismo e constitucionalização do direito: o triunfo tardio do Direito Constitucional no Brasil. Boletim da Faculdade de Direito da Universidade de Coimbra, Coimbra, ano 81, p. 233-289, 2005.

BINENBOJM, Gustavo. Uma teoria do Direito Administrativo: direitos fundamentais, democracia e constitucionalização. 2. ed. São Paulo: Renovar, 2008.

BONAVIDES, Paulo. Curso de Direito Constitucional. 10. ed. São Paulo: Malheiros, 2000.

BRUNA, Sérgio Varella. Agências Reguladoras: poder normativo, consulta pública, revisão judicial. São Paulo: Revista dos Tribunais, 2003.

CADEMARTORI, Luiz Henrique Urquhart; DUARTE, Francisco Carlos. Hermenêutica e argumentação neoconstitucional. São Paulo: Atlas, 2009.

CALSAMIGLIA, Albert. Postpositivismo. Cuadernos de Filosofía del Derecho, Alicante, n. 21-I, p. 209-220, 1998.

CANOTILHO, José Joaquim Gomes. Direito Constitucional e teoria da Constituição. 7. ed. Coimbra: Almedina, 2003.

CARVALHO FILHO, José dos Santos. Agências Reguladoras e poder normativo. Revista Eletrônica de Direito Administrativo Econômico (REDAE), Salvador, n. 9, p. 01-13, fev./abr. 2007. Disponível em: <http://www. direitodoestado.com/revista/REDAE-9-FEVEREIRO-2007-JOSE\%20 CARVALHO.pdf>. Acesso em 03 fev. 2014.

CRISTÓVAM, José Sérgio da Silva. Colisões entre princípios constitucionais: razoabilidade, proporcionalidade e argumentação jurídica. 1. ed. 4. tir. Curitiba: Juruá, 2011.

. O conceito de interesse público no Estado constitucional de direito: o novo regime jurídico administrativo e seus princípios constitucionais estruturantes. 2014. 379 f. Tese (Doutorado em Direito) - Programa de Pós-Graduação em Direito da Universidade Federal de Santa Catarina, Florianópolis, 2014.

DIMOULIS, Dimitri. Neoconstitucionalismo e moralismo jurídico. In: SARMENTO, Daniel (Coord.). Filosofia e teoria constitucional contemporânea. Rio de Janeiro: Lumen Juris, 2009, p. 213-226.

DI PIETRO, Maria Sylvia Zanella. Da constitucionalização do Direito Administrativo: reflexos sobre o princípio da legalidade e a discricionariedade administrativa. In: DI PIETRO, Maria Sylvia Zanella; 
RIBEIRO, Carlos Vinícius Alves (Coord.). Supremacia do interesse público e outros temas relevantes do Direito Administrativo. São Paulo: Atlas, 2010, p. 175-196.

ESPÍNDOLA, Ruy Samuel. Conceito de princípios constitucionais: elementos teóricos para uma formulação dogmática constitucionalmente adequada. 2. ed. São Paulo: Revista dos Tribunais, 2002.

ÊXODO. In: A BÍBLIA SAGRADA. Tradução ecumênica. São Paulo: Paulinas, 2002.

FALDINI, Cristiana Corrêa Conde. A constitucionalização do Direito Administrativo. In: DI PIETRO, Maria Sylvia Zanella; RIBEIRO, Carlos Vinícius Alves (Coord.). Supremacia do interesse público e outros temas relevantes do Direito Administrativo. São Paulo: Atlas, 2010, p. 261-277.

GUASTINI, Ricardo. La "constitucionalización” del ordenamiento jurídico. In: CARBONELL, Miguel (Org.). Neoconstitucionalismo(s). Madrid: Trotta, 2003, p. 49-73.

HARGER, Marcelo. A declaração de inconstitucionalidade de leis e ilegalidade de atos infranormativos por tribunais administrativos. In: NOHARA, Irene Patrícia; MORAES FILHO, Marco Antonio Praxedes de (Org.). Processo Administrativo: temas polêmicos da Lei no 9.784/99. São Paulo: Atlas, 2011, p. 141-158.

HOBSBAWM, Eric J. Era dos extremos: o breve século XX (1914-1991). Tradução de Marcos Santarrita. 2. ed. 26. tir. São Paulo: Companhia das Letras, 1995.

JUSTEN FILHO, Marçal. Curso de Direito Administrativo. São Paulo: Saraiva, 2005.

OLIVEIRA, Rafael Tomaz de. Presidencialismo de coalizão, um velho dilema brasileiro. Revista Eletrônica Consultor Jurídico, São Paulo, mai. 2013. Disponível em: <http://www.conjur.com.br/2013-mai-18/diario-classepresidencialismo-coalizao-velho-dilema-brasileiro>. Acesso em: 02 fev. 2014.

ORWELL, George. A revolução dos bichos: um conto de fadas. Tradução de Heitor Aquino Ferreira. São Paulo: Companhia das Letras, 2007.

OTERO, Paulo. Legalidade e Administração Pública: o sentido da vinculação administrativa à juridicidade. Coimbra: Almedina, 2007. 
RODRÍGUEZ-ARANA MUÑOZ, Jaime. El marco constitucional del Derecho Administrativo: el Derecho Administrativo Constitucional. Anuario da Faculdade de Dereito da Universidade da Coruña, Coruña, n. 15, p. 87-102, 2011.

SARMENTO, Daniel (Org.). Interesses públicos versus interesses privados: desconstruindo o princípio da supremacia do interesse público. Rio de Janeiro: Lúmen Júris, 2005.

. O neoconstitucionalismo no Brasil: riscos e possibilidades. In: . Filosofia e teoria constitucional contemporânea. Rio de Janeiro: Lumen Juris, 2009, p. 113-146.

STRECK, Lenio Luiz. Ontem, os Códigos; hoje, as Constituições: o papel da hermenêutica na superação do positivismo pelo neoconstitucionalismo. In: ROCHA, Fernando Luiz Ximenes; MORAES, Filomeno (Org.). Direito Constitucional contemporâneo: estudos em homenagem ao Professor Paulo Bonavides. Belo Horizonte: Del Rey, 2005, p. 521-561.

WOLKMER, Antonio Carlos. Pluralismo Jurídico: fundamentos de uma nova cultura no direito. 3. ed. São Paulo: Alfa Ômega, 2001.

ZAGREBELSKI, Gustavo. El derecho ductil: ley, derecho y justicia. Traducción de Marina Gascón, Madrid: Trota, 1995. 
